\title{
Strategie ochrany před negativními dopady povodní a erozními jevy prírodě blízkými opatřeními v České republice
}

\section{KAREL DRBAL}

\section{SOUHRN}

Př́spěvek popisuje důvody a okolnosti vzniku projektu Strategie ochrany před negativními dopady povodní a erozními jevy prírodě blízkými opatřeními v České republice, který byl řešen Výzkumným ústavem vodohospodářským T. G. Masaryka, v. v. i., ve spolupráci se sdružením společností Sweco Hydroprojekt a. S., VRV, a. s., SINDLAR Group, s. r. O., a WASTECH, a. s.

\section{ÚVOD}

Vodní režim české krajiny prošel v průběhu 20. století zcela zásadní proměnou. Ta úzce souvisí se změnami uspořádání krajiny, výstavbou dopravní infrastruktury, rozšiřováním zástavby, devastací rozsáhlých ploch v těžebních oblastech, intenzifikací zemědělského hospodaření, odvodňováním, scelováním a rozoráváním pozemků, zhoršením struktury zemědělské půdy, změnou skladby lesa a regulací vodotečí.

$\checkmark$ důsledku těchto a dalších necitlivých zásahů do vodního režimu krajiny a v kombinaci s možnými účinky klimatické změny došlo a stále dochází k negativním projevům povodní a hydrologického sucha s následujícími dopady: zanášení vodotečí a vodních nádrží, splachy ornice do intravilánu obcí, škody na majetku občanů, institucí a společností, snižování úrodnosti a výnosovosti zemědělské půdy, těžebně dopravní eroze na lesní půdě, zhoršení pedohydrologické bilance, snižování hladiny podzemní vody a rozšiřování aridních oblastí na našem území.

Uvedené vyplývá zejména z hodnocení průběhu velkoplošných regionálních povodní v letech 1997 a 2002 až 2013 stejně jako z důsledků katastrofálních povodňových situací vyvolaných přivalovými srážkami (rok 2009) i epizodických lokálních projevů tohoto příčinného jevu. Je ž̌ejmé, že náprava minulých zásahů si vyžádá řadu let a že se bude jednat o částečnou, ale systematickou "rekonstrukci" krajiny. Současně platí, že zmíněná "rekonstrukce", zaměřená mj. na nastavení optimálního vztahu vodního režimu a struktury krajiny, vyžaduje komplexní prístup a využití vícestupňové optimalizace navrhování opatření. Adaptační scénáře na dopady klimatické změny v celé Evropě předpokládají včasnou realizaci soustav preventivních opatření, které v důsledku povedou ke zvýšení retence vody v území a k lepší prípravě celé plochy povodí na negativní vlivy klimatické změny. Dosavadní přístupy prevence jsou poznamenány jistým stupněm roztříštěnosti a mnohdy i nízkou úrovní faktické koordinace.

Plánovací agendy, které se zásadním způsobem promítají do krajiny, jsou vedeny různými subjekty a spravovány obvykle za jiným účelem. Vlastnické vztahy, které jsou tak podstatné (někdy i limitující) pro změnu uspořádání krajiny, protierozní úpravy a návrhy společných zařízení, jsou garantovány stavem katastru nemovitostí a dále metodikou i navazující agendou komplexních pozemkových úprav podle zákona č. 139/2002 Sb. Napríč pomysInou linií vlastnických vztahů v krajině a rozdělení krajiny na katastrálně evidovanou zemědělskou a lesní půdu procházejí plány dílčích povodí, které řeší požadavky Rámcové směrnice o vodách 2000/60/ES a jsou nově zásadním plánovacím nástrojem ve vodním hospodářství. Dalším dưležitým krokem je tvorba územně analytických podkladů (ÚAP) podle vyhlášky č. 500/2006 Sb. a jejich zavedení do územně plánovací agendy krajských úřadů a obcí s rozšírenou působností (ORP). Nicméně souhrnně lze konstatovat, že jsou stále patrné resortní bariéry, nekoordinovanost a nízké využívání datových propojení výše uváděných agend/databází a s tím související efekty z jejich využití v prostorovém plánování.

Komplexní přístup představuje účelné propojení agrotechnických, biotechnických a technických opatření do jedné funkční soustavy zaměřené na zvýšení akumulace vody v území, snížení kulminačních průtoků při povodních a zpomalení průchodů povodňových vin, lepší prípravu území v záplavových oblastech a snižení erozního smyvu ze zemědělské i lesní půdy. Uplatněním uvedeného komplexního prístupu ve využití území dojde k významným synergickým efektům, k finančním úsporám a ke snižení škod na životním prostředí i majetku občanů. Zavedení opatření pouze jednoho typu znamená nevyváženost, která z hlediska trvale udržitelných principů správy území povede ke zvýraznění negativních důsledků možné klimatické změny.

\section{KOMPLEXNÍ PROJEKT JAKO ŘEŠENÍ}

Zásadní skutečnosti v dané věci přineslo usnesení vlády ČR č. 541/2008 ze dne 14. 5. 2008, na jehož základě byla resorty MŽP a MZe vypracována Koncepce řešení problematiky ochrany před povodněmi v České republice s využitím technických a prírodě blízkých opatření. Tato koncepce byla dne 10. listopadu 2010 schválena usnesením vlády ČR č. 799, které uložilo ministrům zemědělství, životního prostředí, financí, pro místní rozvoj a místopredsedovi vlády a ministru vnitra plnit úkoly obsažené v koncepci a predložit vládě zprávu o jejich plnění do 31. prosince 2013.

K plnění značné části úkolů daných uvedeným usnesení vlády byl připraven projekt "Strategie ochrany pred negativními dopady povodní a erozními jevy prírodě blízkými opatřeními v České republice" (dále projekt Strategie). Projekt byl podán na základě 14. výzvy OPŽP, prioritní osa 1 - Zlepšování vodohospodářské infrastruktury a snižování rizika povodní, oblast podpory 1. 3 - Omezování rizika povodní, 1. 3. 1 - Zlepšení systému povodňové služby a preventivní protipovodňové ochrany. Hlavním řešitelem projektu byl výzkumný ústav 
vodohospodářský T. G. Masaryka, v. v. i. Dodavatelsky se na projektu podílelo sdružení společností Sweco Hydroprojekt a. s., VRV, a. S., SINDLAR Group, s. r. O., a WASTECH, a. s. Projekt byl řešen v období od 1. 6. 2014 do 31. 10. 2015.

Z úkolů definovaných usnesením vlády ČR č. 799/2010 byla projektem Strategie ochrany řešena nebo doplňována především následující témata:

- stanovit pro oblasti s významným povodňovým rizikem a jejich povodí zdrojová území s vysokými specifickými odtoky vody včetně jejího urychleného odtoku, území s významným erozním smyvem a území s potenciální retenční kapacitou, včetně kvantifikace retenčního potenciálu;

— zvýšit zaměření environmentálních podpor rozvoje venkova na zatravňování nejzranitelnějších lokalit, zavést další prostředky, např. cílené zatravňování, opatření pro pěstování rychle rostoucích dřevin (RRD) pro energetické využití podél vodních toků v širším pásu údolní nivy i na stávající orné půdě, posílení nástrojů prosazujících povinnost protierozních opatření na ohrožených plochách a zvýšení vsakování vody; řešit priority pro výběr príijemců podpor v zájmových územích s efektem pro povodňovou ochranu;

— analyzovat problematiku finanční spoluúčasti př́mo chráněných subjektů, obcí, krajů a státu na investičních a provozních nákladech ochranných opatření:

- metodicky řešit střet zájmu umístění stavby protipovodňového opatření se zájmy ochrany prírody a krajiny (kompromisními variantami a objektivním hodnocením obou veřejných zájmů);

— analyzovat dosud realizovaná opatření a navrhnout novou metodiku návrhů preventivních protipovodňových strukturálních opatření a jejich posuzování;

- navrhnout prístupy pro zohlednění možných dopadů klimatické změny a potřebu řešit problematiku povodní a sucha komplexně při navrhování parametrů protipovodňových opatření a standardů protipovodňové ochrany;

— analyzovat provedené odvodnění lesních pozemků a navrhnout úpravu na snížení jeho nepříznivého povodňového účinku;

- zpracovat pro vymezená povodí v rámci studií odtokových poměrů návrhy variant komplexního řešení s využitím technických a prírodě blízkých opatření;

— iniciovat výběr výzkumných témat v rámci programů Technologické agentury České republiky zejména v oblastech hodnocení povodňového rizika, výzkumu ochrany před př́valovými srážkami, stanovení návrhových charakteristik povodní, možností ovlivnění retenční schopnosti krajiny, hodnocení účinků řizených a prirrozených rozlivůa ov livnění povodňového režimu antropogenními vlivy a klimatickými změnami a $v$ oblasti ochrany obyvatelstva, měst a obcí před účinky povodní, prevence a řešení krizových stavů, varovné a hlásné služby a fungování integrovaného záchranného systému.

\section{CÍLE PROJEKTU}

\section{Projekt Strategie vznikl především proto, aby umožnil naplnit tyto cíle:}

- Koncepční řešení adaptačních trvale (dlouhodobě) udržitelných opatření (zlepšení protipovodňové ochrany a vodního režimu). Projekt nabízí komplexní a propojený systém opatření, který bude mít za následek synergii účinků celé řady navržených opatření a smysluplné využivání finančních prostředků. Na základě výstupů projektu bude možné realizovat pouze taková opatření, u nichž by byla dopředu známa jejich předpokládaná účinnost (protipovodňová i environmentální).

— Vytvořit jednotný přístup $k$ analýze povodí nebo krajiny dotčené povodněmi $\checkmark$ rámci vícekriteriálního hodnocení povodňových rizik a návrhů opatření na lokální i regionální úrovni.

- Vytvořit jednotný metodický prístup k umístění opatření a výpočtu jejich účinků včetně ekonomických nákladů.
- Vytvorit jednotnou platformu výstupů pro veřejnost (internetová prezentace) a strategické plánování (podklady pro územní plány a vodohospodárské plány).

- Navrhnout opatření na tocích, která zároveň zlepší hydromorfologické vlastnosti toků, zvýší jejich ekologicko-stabilizační funkce a současně zvýší ochranu území před negativními účinky povodní.

- Navrhnout opatření v ploše povodí, která sníži erozní odnos půdy, zlepší retenci vody v krajině a přispěje ke zvýšení ekologické stability krajiny.

Kromě vlastních návrhů opatření si projekt Strategie kladl za cíl iniciovat proces úprav dotčených právních norem k zrychlení procesu realizace komplexu protipovodňových opatření.

\section{ROZSAH A PODROBNOST ŘEŠENÍ PROJEKTU}

V rámci projektu nebylo možné řešit celé území České republiky stejně podrobně. Byl tedy proveden výběr území z hlediska rizika povodní a eroze. Pro tuto kategorizaci byla uplatněna tři hlediska:

- povodňové ohrožení trvale bydlících osob,

- povodňové ohrožení majetku,

- erozní ohroženost.

Bylo přistoupeno ke kategorizaci území České republiky podle míry ohrožení: velmi vysoká, vysoká a střední míra ohrožení (obr. 1) podle průniku výše citovaných kritérií v rámci povodí vyšších řádů (IV. a III.), tj. malých povodí o ploše $\checkmark$ desítkách, popř. stovkách kilometrů. Míra přesnosti detailu tak nemohla být logicky velká, ale posloužila k základnímu rozdělení pracnosti projektu.

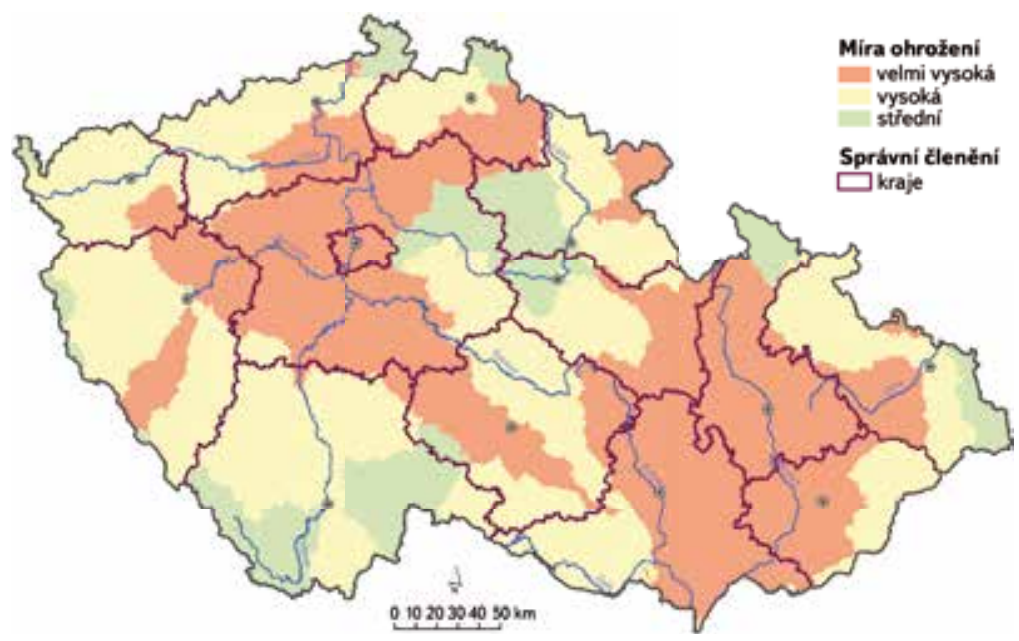

Obr. 1. Kategorizace území ČR podle míry ohrožení povodněmi a erozí

Fig. 1. Categorisation of the Czech Republic by flood and erosion threat

Údaje pro kategorizaci území byly využity z přípravných prací z plnění směrnice o vyhodnocení a zvládání povodňových rizik (etapa předběžného vyhodnocení povodňových rizik).

Důležité je však vědět, že analytické práce pro celé území České republiky byly provedeny na stejné úrovni podrobnosti a jednotlivé kategorie území se liší pouze mírou podrobnosti zpracování návrhů opatření. Zatímco oblast se střední mírou ohrožení není zpracovávána do úrovně opatření, kategorie s vysokou mírou ohrožení již opatření zpracovávána má, ale pouze jako skupinu opatření, a kategorie s velmi vysokou mírou ohrožení je řešená v podstatě do detailů. Úroveň druhou a třetí lze tedy v budoucnu dopracovat do úrovně s nejvyšší mírou ohrožení, a to $v$ těch lokalitách, kde to bude naléhavé. 
Kategorizace byla provedena především proto, aby se tak rozsáhlý projekt dal vůbec časově a finančně zvládnout. Ostatní území lze podobnými odbornými kroky dopracovávat.

\section{ZÁVAZNOST NAVRŽENÝCH OPATŘENÍ}

Opatření navržená v projektu Strategie nejsou legislativně závazná, přesto je v posledních několika letech vytvářena společenská i politická potřeba jejich realizace.

Jejich potřebnost vyplývá z vládních usnesení, která se zabývala Plánem hlavních povodí České republiky - usnesení vlády ze dne 23. května 2007 Č. 562, dále strategií protipovodňové ochrany v ČR - usnesení ze dne 10. listopadu 2010 č.799 ke Koncepci řešení problematiky ochrany před povodněmi v České republice $s$ využitím technických a prírodě blízkých opatření nebo usnesení z roku 2009 ze dne 26. srpna č. 1058 k Informaci o zlepšení předpovědní a výstražné služby Českého hydrometeorologického ústavu a o návrhu Projektu řešení problematiky ochrany před povodněmi v České republice s využitím prrírodě blízkých opatření.

Potřeba jejich realizace vyplývá neprímo z obou již jmenovaných evropských směrnic - Rámcové směrnice o vodní politice (2000/60/ES) a směrnice o vyhodnocování a zvládání povodňových rizik (2007/60/ES). Zde jsou jednoznačně preferována taková opatření, která nezhorší stav vod a umožní využití prostoru niv pro přirozené či řizené inundace.

Navrhovaná opatření se mohou stát závazná až v okamžiku, kdy se stanou pevnou součástí některých strategických nástrojů rozvoje území, jakými jsou např. územní plán nebo plán dílčího povodí, popř. plánu společných zařízení jako jednoho z výsledků procesu pozemkových úprav.

Výsledky projektu, resp. návrhy opatření budou podporovány dotačním titulem OPŽP, a tím mohou být i predmětem evropských dotací.

\section{ZÁVĚR}

Svým charakterem a výsledky je projekt Strategie komplexní projekt infrastrukturní povahy pro univerzální dlouhodobé využití, který zásadním způsobem umožňuje vyhodnotit pro celé území státu celospolečenskou prospěšnost a finanční a věcné parametry projektů žadatelů předkládaných do dotačních programů. Výstupy projektu budou vytvářet ucelenou strategii MŽP k řešení problematiky protipovodňové ochrany, plošného znečištění, vodní eroze a obnovy vodního režimu.

\section{Autor}

Ing. Karel Drbal, Ph.D.

凶karel_drbal@vuv.cz

Výzkumný ústav vodohospodářský T. G. Masaryka, v. v. i., pobočka Brno

\section{STRATEGY FOR PROTECTION AGAINST NEGATIVE IMPACTS OF FLOODS AND EROSION PHENOMENA BY NATURE-FRIENDLY MEASURES IN THE CZECH REPUBLIC}

\section{DRBAL, $K$.}

\section{TGM Water Research Institute, p. r. i., Brno branch}

The article describes reasons and circumstances why the project "Strategy of flood and erosion protection by natural water retention measures" was initiated. This project was solved by T. G. Masaryk Water Research Institute, p. r. i., and a group of companies - Sweco Hydroprojekt a. s., VRV, a. S., SINDLAR Group, s. r. O., WASTECH, a. s. 